\title{
BMPR1a Signaling Determines Numbers of Oligodendrocytes and Calbindin-Expressing Interneurons in the Cortex
}

\author{
Jayshree Samanta, ${ }^{1}$ Gordon M. Burke, ${ }^{1}$ Tammy McGuire, ${ }^{1}$ Anna J. Pisarek, ${ }^{1}$ Abhishek Mukhopadhyay, ${ }^{1}$ Yuji Mishina, ${ }^{2}$ \\ and John A. Kessler ${ }^{1}$ \\ ${ }^{1}$ Department of Neurology, Feinberg School of Medicine, Northwestern University, Chicago, Illinois 60611, and ${ }^{2}$ Laboratory of Reproductive and \\ Developmental Toxicology, National Institute of Environmental Health Sciences, Research Triangle Park, North Carolina 27709
}

\begin{abstract}
Progenitor cells that express the transcription factor olig1 generate several neural cell types including oligodendrocytes and GABAergic interneurons in the dorsal cortex. The fate of these progenitor cells is regulated by a number of signals including bone morphogenetic proteins (BMPs) secreted in the dorsal forebrain. BMPs signal by binding to heteromeric serine-threonine kinase receptors formed by type I (BMPR1a, BMPR1b, Alk2) and type II (BMPRII) subunits. To determine the specific role of the BMPR1a subunit in lineage commitment by olig1-expressing cells, we used a cre/loxP genetic approach to ablate BMPR1a in these cells while leaving signaling from other subunits intact. There was a reduction in numbers of immature oligodendrocytes in the BMPR1a-null mutant brains at birth. However, by postnatal day 20, the BMPR1a-null mice had a significant increase in the number of mature and immature oligodendrocytes compared with wild-type littermates. There was also an increase in the proportion of calbindin-positive interneurons in the dorsomedial cortex of BMPR1a-null mice at birth without any change in the number of parvalbumin- or calretinin-positive cells. These effects were attributable, at least in part, to a decrease in the length of the cell cycle in subventricular zone progenitor cells. Thus, our findings indicate that BMPR1a mediates the suppressive effects of BMP signaling on oligodendrocyte lineage commitment and on the specification of calbindin-positive interneurons in the dorsomedial cortex.
\end{abstract}

Key words: BMPR1a; Olig1; calbindin; knock-out mice; oligodendrocyte; stem cell

\section{Introduction}

Oligodendrocytes and the majority of cortical GABAergic interneurons arise from a common population of progenitor cells in the ventral telencephalon (Anderson et al., 1997; He et al., 2001; Stuhmer et al., 2002; Yung et al., 2002). Generation of both oligodendrocytes and interneurons is fostered by Shh (sonic hedgehog) (Poncet et al., 1996; Pringle et al., 1996; Yung et al., 2002; Xu et al., 2005) and inhibited by bone morphogenetic proteins (BMPs) (Mehler et al., 1995; Gulacsi and Lillien, 2003). BMPs bind to heteromeric receptors formed by type I (BMPR1a, BMPR1b, Alk2) and type II (BMPRII) subunits (Koenig et al., 1994; ten Dijke et al., 2003). Several studies suggest that BMPR1b mediates the effects of BMPs on exit from cell cycle and terminal differentiation of progenitor cells (Panchision et al., 2001; Gulacsi and Lillien, 2003; Brederlau et al., 2004). However, null mutation of BMPR1b produces no apparent phenotype in the nervous system (Yi et al., 2000), whereas loss of BMPR1a leads to abnormal early forebrain development (Davis et al., 2004) and loss of choroid plexus later in development (Hebert et al., 2002). Double mutation of BMPR1a and BMPR1b leads to loss of dorsal

\footnotetext{
Received Sept. 20, 2006; revised May 25, 2007; accepted May 31, 2007. We thank Q. R. Lu and David H. Rowitch for providing Olig1-cre mice.

Correspondence should be addressed to John A. Kessler, 303 East Chicago Avenue, Ward 10-233, Chicago, IL 60611. E-mail: jakessler@northwestern.edu.

DOI:10.1523/JNEUROSCI.1434-07.2007

Copyright $\odot 2007$ Society for Neuroscience $\quad$ 0270-6474/07/277397-11\$15.00/0
}

interneuron DI1 and reduction in the DI2 population (Wine-Lee et al., 2004) along with reduction of astrocytes and mature oligodendrocytes in the spinal cord (See et al., 2007). Thus, it is unclear which receptor mediates effects of BMPs on either oligodendrocyte or interneuron development in the forebrain.

BMPRla is the predominant receptor during the period of oligodendroglial and interneuron generation (Dewulf et al., 1995; Zhang et al., 1998). Because BMPR1a-null mutant mice die during gastrulation (Mishina et al., 1995), we generated conditional BMPR1a-null mice to study the role of this receptor in neural lineage commitment. Oligodendrocytes are derived from progenitor cells that all express the transcription factors Olig1 and Olig2 (Lu et al., 2000; Zhou et al., 2000). Hence, to study the role of BMPR1a signaling, we ablated BMPR1a specifically in Olig1-expressing progenitors (Lu et al., 2000), whereas BMP signaling through the other receptors remained intact in these cells. At birth, the BMPR1a-null brains had fewer immature oligodendrocytes, but by postnatal day 20 (P20), their brains had significantly higher numbers of immature and mature oligodendrocytes compared with wild-type (WT) mice. There was also a significant increase in the number of calbindin-expressing interneurons in the dorsomedial cortex at birth. These effects were attributable, at least in part, to a decrease in the length of the cell cycle in subventricular zone (SVZ) progenitor cells. Thus, our findings indicate that BMPR1a mediates the suppressive effects of BMP signaling on oligodendroglial and interneuron lineage commitment. 


\section{Materials and Methods}

Generation and maintenance of mouse lines. Olig1-cre mice were maintained in C57BL/6J and BMPR1a-fx mice were maintained in a mixed 129SvJ:C57BL/6 (3:1) background. The generation of olig1-cre mice (Lu et al., 2002) and BMPR1a-fx mice (Mishina et al., 2002) and their genotyping has been described previously. We mated Olig $1^{\text {cre/cre }}$ mice with heterozygous BMPR1a-null mutant $\left(\mathrm{BMPR} \mathrm{a}^{+/-}\right.$) mice to obtain Olig $1^{\text {cre/+ }}$ BMPR1a ${ }^{+/-}$mice, which were then mated with homozygous floxed-BMPR1a (BMPR1a ${ }^{\mathrm{fx}_{\mathrm{fx}}}$ ) mice to obtain four types of mice:

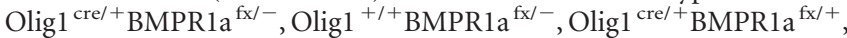
and Olig $1^{+/+}$BMPR $1 a^{\mathrm{fx} /+}$. Olig $1^{\text {cre/+}}$ BMPR $1 a^{\mathrm{f} \times /-}$ mice have BMPRla knocked out specifically in Olig1-expressing cells, referred to as knockout (KO) mice (see Fig. 1). Olig1cre/cre mice were mated with floxed Rosa26 mice (The Jackson Laboratory, Bar Harbor, ME) to generate Olig1cre/+;R26R mice.

$\beta$-Galactosidase assay. Brains from P4 Olig1cre/R26 mice were harvested, and 5-bromo-4-chloro-3-indolyl- $\beta$-D-galactopyranoside (X-gal) staining was done according to the method described by Stuhmer et al. (2002). Briefly, the whole brains were cut into $1 \mathrm{~mm}$ coronal sections and fixed in $0.2 \%$ paraformaldehyde (PFA). Sections were then washed in rinse buffer $\left(0.1 \mathrm{~m}\right.$ phosphate buffer, $\mathrm{pH} 7.3,2 \mathrm{~mm} \mathrm{MgCl}_{2}, 20 \mathrm{~mm}$ Tris, $\mathrm{pH} 7.3,0.01 \%$ sodium deoxycholate, and $0.02 \%$ Nonidet P- 40 ) and incubated overnight at $37^{\circ} \mathrm{C}$ in staining solution (rinse buffer supplemented with $5 \mathrm{~mm}$ potassium ferricyanide, $5 \mathrm{~mm}$ potassium ferrocya-

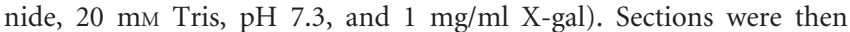
postfixed in 10\% formalin overnight and cleared in $70 \%$ ethanol.

Immunohistochemistry. Mice were anesthetized and perfused with cold PBS, the brains were fixed and cryoprotected in 4\% PFA and 20\% sucrose solution overnight, and immunohistochemistry was performed on cryosections. After washing in PBS, heat-induced antigen retrieval was done using $10 \mathrm{~mm}$ sodium citrate, $\mathrm{pH}$ 6. The sections were then blocked for $1 \mathrm{~h}$ in blocking solution containing $10 \%$ goat serum and $1 \%$ BSA along with $0.25 \%$ Triton X-100 and incubated overnight at $4^{\circ} \mathrm{C}$ in primary antibody. Sections were then washed and incubated with fluorophore-conjugated secondary antibody (1:500; Invitrogen, Carlsbad, CA) in the dark for $1 \mathrm{~h}$ at room temperature. The nuclei were counterstained with Hoechst (Invitrogen). Primary antibodies used were rabbit polyclonal antibodies to detect Olig1 (1:200; Chemicon, Temecula, CA); NG2 (1:200; Chemicon); cleaved caspase 3 (1:1000; Cell Signaling Technology, Beverly, MA); Ki67 (1:1000; Vision BioSystems, Newcastle Upon Tyne, UK); $S 100 \beta$ (1: 1000; Dako, Glostrup, Denmark); calbindin (1: 5000; Swant, Bellinzona, Switzerland); calretinin (1:1000; Swant); parvalbumin (1:1000; Swant); GABA (1:1000; Sigma, St. Louis, MO); cre recombinase (1:200; Covance, Berkeley, CA); proteolipid protein (PLP; 1:500; Abcam, Cambridge, MA); GSH2 (1:5000; a gift from Kenneth Campbell, Childrens Hospital Research Foundation, Cincinnati, $\mathrm{OH}$ ); rat monoclonal antibody to detect PDFGR $\alpha$ (1:200; BD Biosciences, San Jose, CA); chick polyclonal antibody to detect $\beta$-galactosidase ( $\beta$ gal; 1:200; Abcam); and mouse monoclonal antibodies to detect CNPase (1:200; Covance); myelin basic protein (MBP; 1:500; Covance); GFAP (1:100; Sigma); neuronal-specific nuclear protein (NeuN; 1:500; Chemicon); cre recombinase (1:100; Covance); $\beta$-galactosidase (1:500; Invitrogen); pan-axonal neurofilament (1:500; Covance); calbindin (1:1000; Swant); and proliferating cell nuclear antigen (PCNA; 1:500; BD Biosciences) immunoreactivity. Three to five mice were analyzed in each group, i.e.,

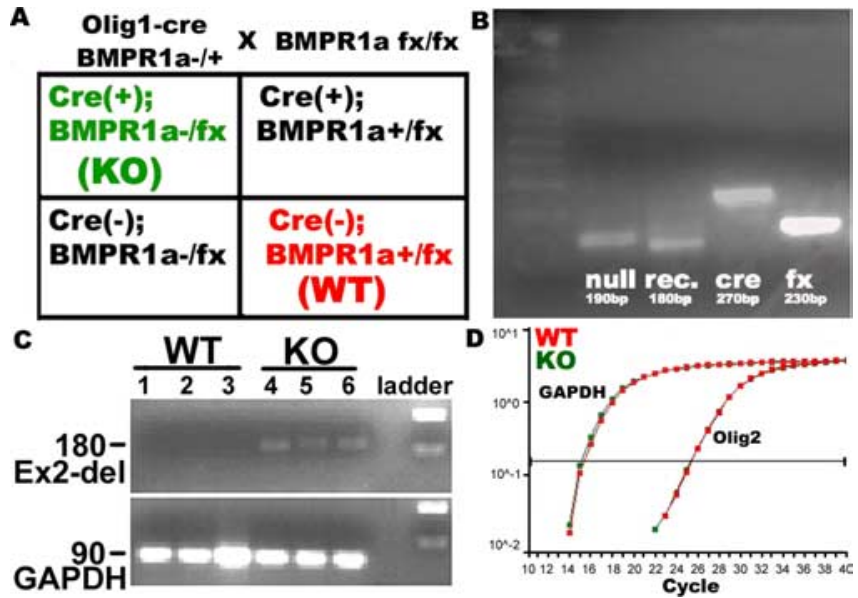

Figure 1. Ablation of BMPR1a mediated by 0lig1-cre results in postnatal lethality. $\boldsymbol{A}, \boldsymbol{B}$, Olig1 ${ }^{\text {cre/+ }} ; \mathrm{BMPR} 1 \mathrm{a}^{+/-}$mice were mated with BMPR1a ${ }^{\mathrm{fx} / \mathrm{fx}}(\boldsymbol{A})$, and recombination was confirmed in the brain by extracting genomic DNA followed by PCR genotyping $(\boldsymbol{B})$. The BMPR1anull allele (null) and (re recombinase (cre) expression were both present. Because whole brain contained a mixture of 0lig1-Cre-expressing cells and nonexpressing cells, both an unrecombined floxed band ( $\mathrm{fx}$ ) and a recombined BMPR1a band (rec.) were detected. C, Cre-dependent recombination was detected by RT-PCR done with $m R$ RA extracted from $P 21$ whole brain. All of the mice that carried Olig1-cre showed deletion of BMPR1a exon2. D, Expression of mRNA for Olig2 was analyzed by quantitative RT-PCR performed with mRNA extracted from whole brains of PO WT and KO mice. BMPR1a mutation did not change the levels of Olig2 transcripts.

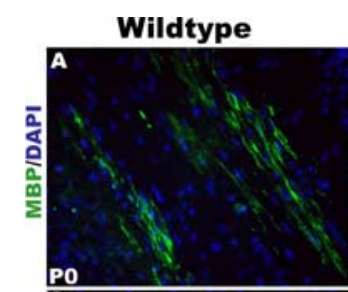

BMPR1a mutant
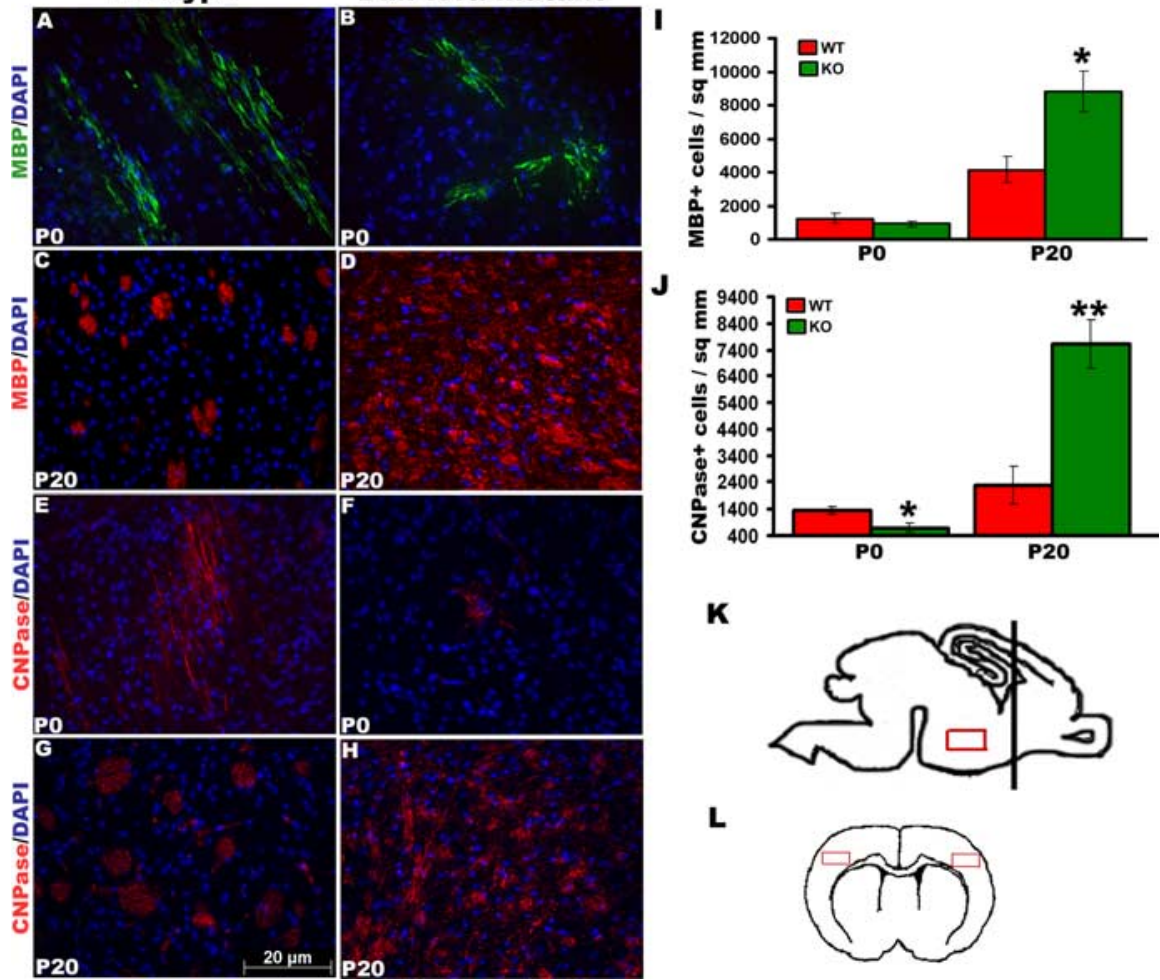

$\mathbf{K}$

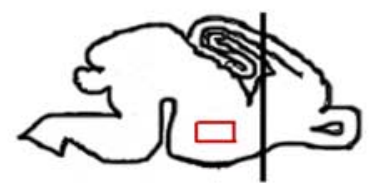

$\mathbf{L}$

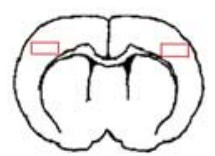

Figure 2. BMPR1a KO mice have increased numbers of mature oligodendrocytes. $A-J$, Immunohistochemistry was done for $\operatorname{MBP}(\boldsymbol{A}-\boldsymbol{D})$ and CNPase $(\boldsymbol{E}-\boldsymbol{H})$ in brain sections from P0 and P20 mice, and cell counts were done using Volocity $(\boldsymbol{I}, \boldsymbol{J}) . \boldsymbol{K}, \boldsymbol{L}$, Sagittal sections were used to analyze the ventral diencephalon of $\mathrm{PO}$ brains $(\boldsymbol{K})$, and coronal sections were used to analyze the cortex of P20 brains $(\boldsymbol{L})$. The black bar in $\boldsymbol{K}$ denotes the position of coronal sections, and the red boxes are the areas in which cell counts were done. At P0, the KO mice have lower numbers of CNPase + cells $(\boldsymbol{E}, \boldsymbol{F}, \boldsymbol{J})$, whereas at P20, the numbers of CNPase + and MBP + cells are significantly increased $(\boldsymbol{A}-\boldsymbol{D}, I)$. ${ }^{*} p=0.02, t$ test, $n=5 ;{ }^{* *} p=0.002, t$ test, $n=5$. Error bars represent SEM. DAPI, $4^{\prime}, 6^{\prime}$-Diamidino-2-phenylindole dihydrochloride. 

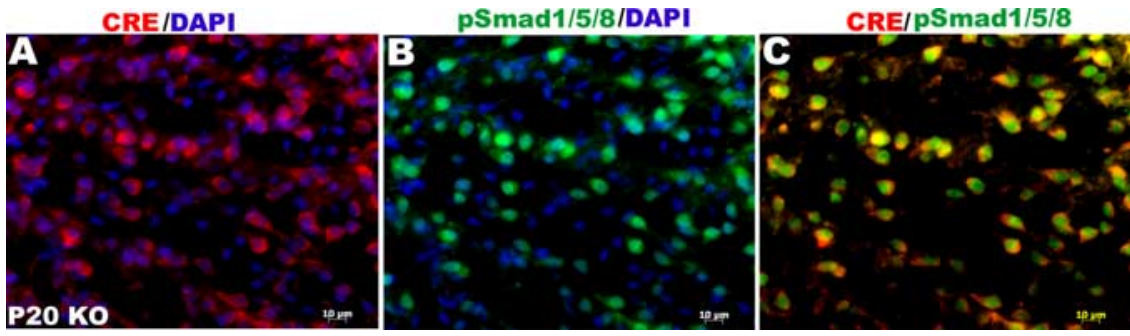

Figure 3. Smad $1 / 5 / 8$ signaling persists in the BMPR1a-null cells. Sections of P20 brains were immunostained for cre and pSmad1/ $5 / 8 . A, B$, Virtually all cells expressing cre recombinase $(\boldsymbol{A})$ show nuclear $\mathrm{pS}$ mad $1 / 5 / 8(\boldsymbol{B})$. Cytoplasmic staining for $p 5 \mathrm{Smad} 1 / 5 / 8$ was also present in some cells. $A, C$, Cre staining was cytoplasmic as expected. DAPI, $4^{\prime}, 6^{\prime}$-Diamidino-2-phenylindole dihydrochloride.

\section{Wildtype}
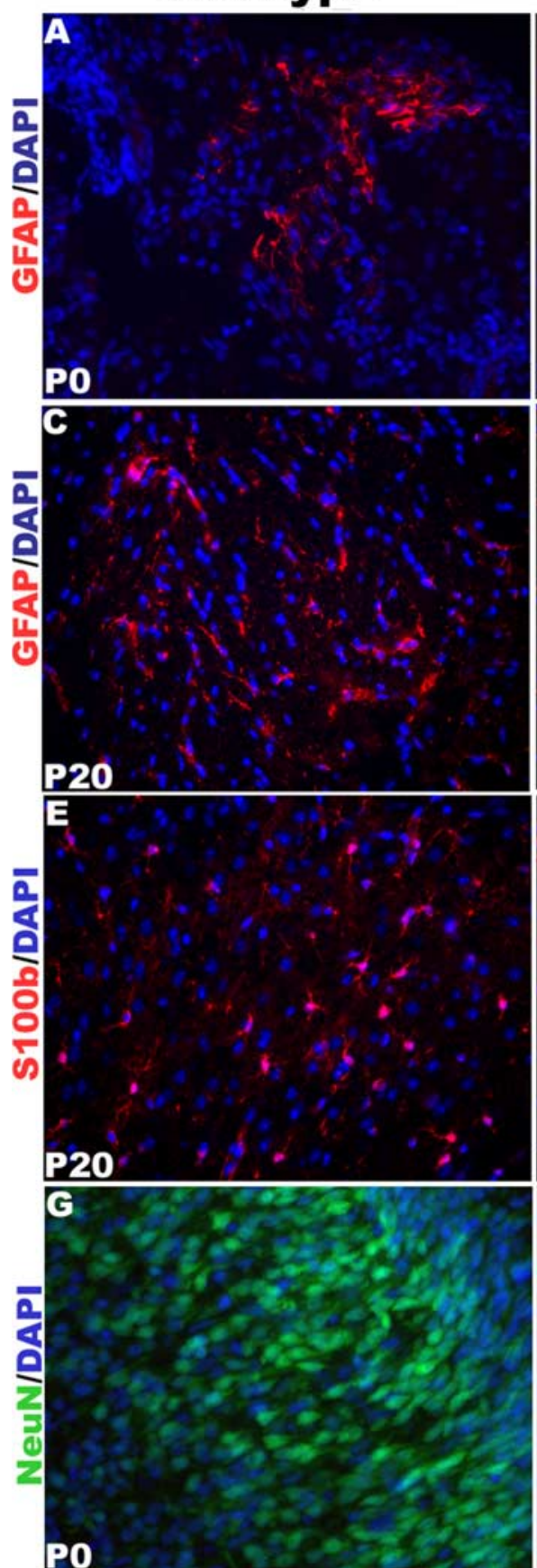

Figure 4. BMPR1a-null mutant mice have no change in the number of neurons or astrocytes. $\boldsymbol{A}-\boldsymbol{H}$, Immunohistochemistry was done for GFAP $(\boldsymbol{A}-\boldsymbol{D}), \operatorname{S100} \beta(\boldsymbol{E}, \boldsymbol{F})$, and $\operatorname{NeuN}(\boldsymbol{G}, \boldsymbol{H})$ in brain sections from P0 and P20 mice. Expression of markers was analyzed in the dorsal forebrain, except for that of GFAP and $S 100 \beta$ in PO mice, in which the analysis was done in the ventral diencephalon. The $K 0$ and WT brains had similar numbers of astrocytes and neurons. DAPI, 4',6' ${ }^{\prime}$-Diamidino-2-phenylindole dihydrochloride. knock-out (Olig1 ${ }^{\text {cre/+ }}$ BMPR1a ${ }^{\mathrm{fx} /-}$ ) and wild-type $\left({\text { BMPR } 1 \mathrm{a}^{\mathrm{f}} \mathrm{f} /+}\right.$ ) groups. For Nissl staining of neurons, we used NeuroTrace red fluorescent stain (Invitrogen) and followed the manufacturer's protocol.

Cell counts and statistical analysis. Coronal cryosections including the sensory cortex were obtained starting from the genu of the corpus callosum to the hippocampal commissure. Serial sections from each mouse were immunostained with different antibodies. Images were acquired using Zeiss (Oberkochen, Germany) fluorescent microscope. Colocalization of proteins were detected using Zeiss LSM510 laser-scanning confocal microscope in the Northwestern University Cell Imaging Facility. The average counts were determined from at least three fields per hemisphere, and the area counted was from $2 \mathrm{~mm}$ away from the midline extending laterally to the junction of primary and secondary somatosensory cortex. Five sections were analyzed from each brain, and cell counts were digitally obtained by using the software Volocity (Improvision, Lexington, MA). We set the parameters based on the intensity, size, and shape of expression of the different markers to count cells and used the same settings for all of the mice in the group, thus minimizing variability across sections as well as animals during counting. We also did manual cell counts using NIH ImageJ on some slides selected randomly and got results similar to those obtained using Volocity. The examiner was blinded while acquiring images and counting cells. Student's two-tailed $t$ test assuming unequal variance was applied for statistical analysis.

Quantitative real-time PCR. Quantitative realtime PCR (QRT-PCR) was performed using the PerkinElmer (Wellesley, MA) ABI Prism 7700 Sequence Detector System. Total RNA was extracted from P0 and P21 whole brains of WT and KO mice using Trizol reagent (Invitrogen). cDNA was prepared with thermoscript RT-PCR kit (Invitrogen). QRT-PCR was done with an initial denaturation of $10 \mathrm{~min}$ at $95^{\circ} \mathrm{C}$, followed by $40 \mathrm{cy}$ cles of $15 \mathrm{~s}$ denaturation at $95^{\circ} \mathrm{C}$ and $1 \mathrm{~min}$ of annealing and elongation at $60^{\circ} \mathrm{C}$. SYBR green 1 dye was used to produce the fluorescent signal, which was detected at the annealing phase. Specificity of the PCR was confirmed by running the PCR products on $2 \%$ agarose gel. Two replicates were run for each cDNA sample, with the test and control primers in separate wells of a 96-well plate. An amplification plot showing cycle number versus the change in fluorescent intensity was generated by Sequence Detector program. Primer sequences were as follows: Olig2, CTGCTGGCGCGAAACTACAT (forward) and CGCTCACCAGTCGCTTCAT (reverse); GSH2, ACTACCTACAACATGTCGGACCCA (forward) and CTGGTAAACGCTGTCCTCATCCTT (reverse); GAPDH, GTCGTGGATCTGACGTGCC (forward) and TGCCTGCTTCACCACCTTC (reverse); BMPR1a (intact) and BMPR1a (exon2 deletion) (Mishina et al., 2004).

\section{Results}

BMPR1a mutation in Olig1-expressing cells results in postnatal lethality

To investigate the role of BMPR la signaling in oligodendrogenesis, we used BMPR1a 
conditional null mutant mice in which exon 2 encoding one-third of the extracellular ligand binding domain is floxed, and tissue-specific recombination has been reported previously (Ahn et al., 2001; Hebert et al., 2002; Mishina et al., 2002; Andl et al., 2004; Davis et al., 2004; Ming Kwan et al., 2004; Mishina et al., 2004; Stottmann et al., 2004; Yuhki et al., 2004; Gaussin et al., 2005). By using a well characterized Olig1-cre transgene ( $\mathrm{Lu}$ et al., 2002), we disrupted the function of BMPR1a in olig1-expressing progenitor cells in the CNS. We detected mRNA encoding BMPRla with deleted exon 2 only in brains of the BMPR1a-null (KO) mice (Fig. $1 B, C$ ). The whole brains of these mice showed $\sim 80 \%$ reduction in mRNA encoding the intact BMPRla receptor compared with WT brains ( $p=$ $0.000123 ; n=3$; data not shown), suggesting that Olig1-positive progenitors constitute a large proportion of the BMPRlaexpressing cells. The $\mathrm{KO}$ mice were grossly indistinguishable from their WT littermates at birth but ceased to gain weight after $\mathrm{P} 10$, resulting in a $50 \%$ decrease in body weight at P20 compared with WT mice $(p<0.05 ; n=6)$ (data not shown). These mice did not survive beyond P25. Because olig-expressing cells generate motor neurons as well as oligodendrocytes, we considered the possibility that motor neurons failed to develop normally in the BMPR1a-KO mice. However, there were no obvious changes in the population of motor neurons in the brainstem, and there were no apparent differences between WT and KO mice with immunocytochemistry for islet 1 or HB9 (data not shown). Although it is still possible that there are functional abnormalities of the motor neurons, the animals crawl and suckle without apparent abnormalities as neonates, and they walk without apparent difficulty over the ensuing 2 weeks.

Olig1-cre mice have a cre;PGKneo cassette knocked into the Olig1 locus (thus disrupting the gene), but heterozygous Olig1cre mice are viable and do not show the subtle phenotype of delayed oligodendrocyte maturation observed in the homozygous null mice (Lu et al., 2002). The presence of the cre;PGKneo cassette in the Olig1 locus is thought to induce Olig2 expression, because these two genes are located in the same region of chromosome 16. However, we did not observe any change in the levels of Olig2 mRNA between the KO and WT brains (Fig. 1D).

\section{Ablation of BMPR1a changes the numbers of immature and mature oligodendrocytes}

Oligodendroglial progenitors progress through several biochemical and morphological stages. The basic helix-loop-helix transcription factors Olig1 and Olig2 are the earliest transcription factors expressed in oligodendroglial progenitors (Lu et al., 2000; Zhou et al., 2000). These progenitors then express plateletderived growth factor receptor (PDGFR) and NG2 (Nishiyama et al., 1996) followed by 2'3'-cyclic nucleotide $3^{\prime}$-phosphodiesterase (CNPase). Finally, mature oligodendrocytes express $\mathrm{MBP}$ along with other myelin proteins. At birth (P0), mature oligodendrocytes are predominantly found in the ventral diencephalon (Fig. $2 A, B, E, F$ ), whereas the dorsal forebrain principally contains oligodendroglial progenitors. BMP signaling inhibits the maturation of these progenitors in vitro (See et al., 2004) in addition to inhibiting oligodendroglial lineage commitment by multipotent neural progenitor cells (Samanta and Kessler, 2004). To investigate the role of BMPR1a signaling in the generation of mature oligodendrocytes in vivo, we examined the ventral diencephalon in sagittal sections of P0 brains and the cortex in coronal sections of P20 brains for the expression of CNPase and MBP, which label immature and mature oligodendrocytes, respectively (Fig. $2 K, L$ ). At birth, we observed a significant twofold reduction in immature oligodendrocytes marked by CNPase (Fig. 2E,F) in the KO mice. There was no significant difference in the number of mature oligodendrocytes at this stage, although there was a trend toward a decrease (Fig. $2 A, B$ ) in the ventral diencephalons of $\mathrm{KO}$ mice. However, by P20 there was a significant twofold increase in the density of both CNPase- and $\mathrm{MBP}$-expressing cells in the forebrains of $\mathrm{KO}$ mice compared with the WT littermates (Fig. 2C, D, G-J). We colabeled axons in the corpus callosum with a pan-axonal neurofilament marker and myelin sheath with PLP to examine myelination (supplemental Fig. 2G,H, available at www.jneurosci.org as supplemental material). The axons colocalized with myelin, suggesting that myelination is not affected in the $\mathrm{KO}$ mice. These results indicate that signaling via BMPR1a is responsible for limiting the number of mature oligodendrocytes in the forebrain in vivo. 

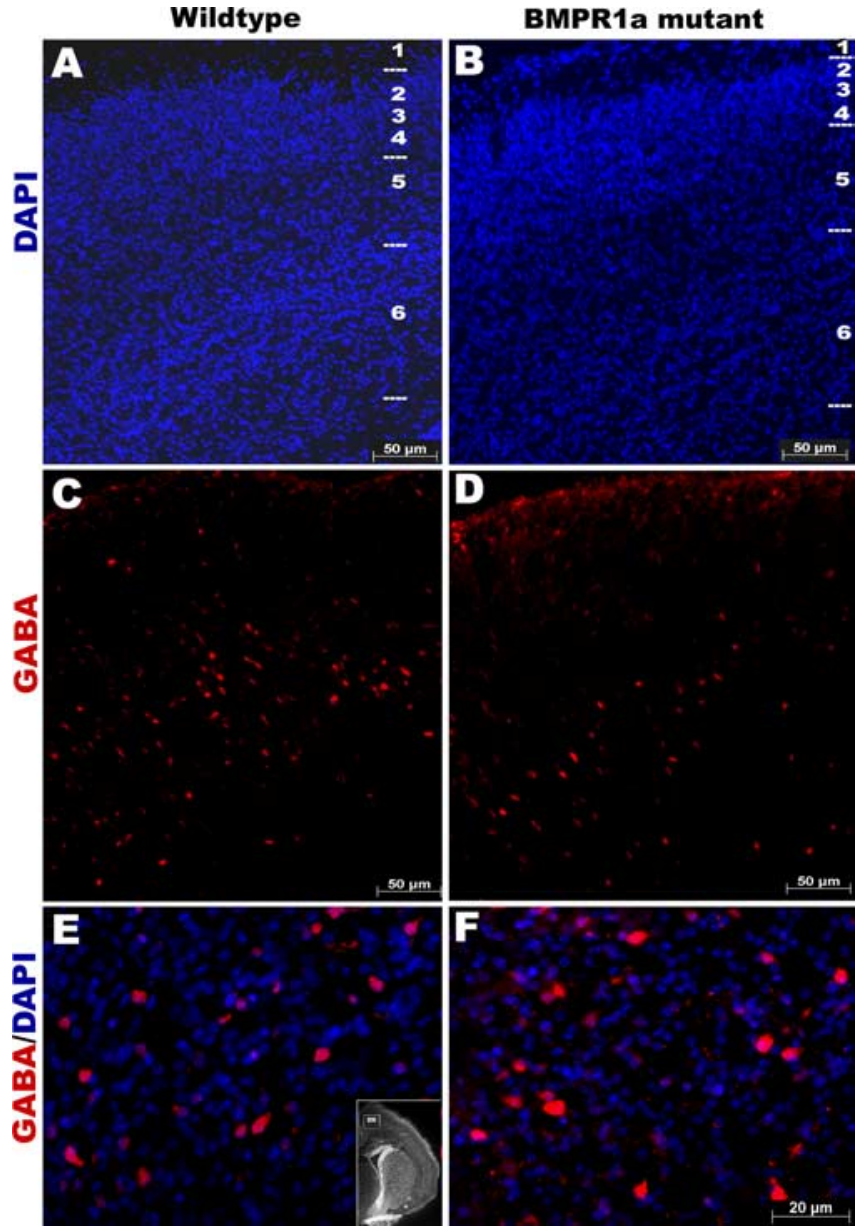

Figure 6. BMPR1a mutation does not regulate the total number of GABAergic interneurons. $\boldsymbol{A}, \boldsymbol{B}$, The nuclei in the P0 dorsomedial cortex (inset in $\boldsymbol{E}$ shows the area examined) are stained with DAPI to show the cortical layers. $\boldsymbol{C}-\boldsymbol{F}$, Immunohistochemistry for GABA shows no change in the number of GABAergic interneurons of BMPR1a mutant mice compared with wild-type littermates. A higher magnification of layer $V$ is shown in $\boldsymbol{E}$ and $\boldsymbol{F} . n=5$. DAPI, $4^{\prime}, 6^{\prime}$-Diamidino2-phenylindole dihydrochloride.

\section{Smad1/5/8 signaling persists in the Olig-cre cells}

Because BMPs signal in part by phosphorylating Smad1/5/8 (pSMAD), we examined Olig1-cre-expressing cells for $\mathrm{p}-\mathrm{SMAD}$ to determine whether signaling through BMP receptors other than BMPR1a remained intact in these cells (Fig. 3). Virtually every olig1-positive cell stained for p-SMAD. In most of these cells, the p-SMAD staining was primarily nuclear, whereas the cre staining was cytoplasmic, as expected. However, in a small proportion of the cells, the p-SMAD staining was both nuclear and cytoplasmic. These observations indicate that other receptors that signal through Smad1/5/8 remain functional in the BMPR1a-null cells.

\section{Signaling via BMPR1a does not regulate the number of astrocytes and neurons}

BMP signaling exerts differing effects on lineage commitment by neural progenitor cells at different stages of development. Early in mouse cortical development [embryonic day 13 (E13)], BMP signaling promotes neuronal lineage commitment by cultured neural progenitor cells (Li et al., 1998; Mabie et al., 1999), whereas later in development (E16 and thereafter), it promotes astrocytic differentiation of ganglion eminence progenitor cells (Mehler et al., 1995; Gross et al., 1996; Zhu et al., 1999), cortical progenitor cells (Mabie et al., 1999), and oligodendroglial pro- genitors (Mabie et al., 1997; Grinspan et al., 2000). Olig1expressing progenitors normally have the potential to differentiate into neurons and oligodendrocytes (Lu et al., 2002; Zhou and Anderson, 2002), but mutation of Olig1 and Olig2 drives the cells toward an astrocytic lineage (Zhou and Anderson, 2002). To examine the effects of ablation of BMPR1a on the numbers of astrocytes, we analyzed the ventral diencephalon in sagittal sections of $\mathrm{P} 0$ brains and the cortex in coronal sections of $\mathrm{P} 20$ brains for the expression of GFAP and $S 100 \beta$. To examine the effect of null mutation of BMPR1a on neurons, we analyzed the expression of NeuN in the cortex of P0 and P20 brains in coronal sections. At both ages, there were no significant differences in the numbers of astrocytes (Fig. $4 A-D$ ) or neurons (Fig. $4 G, H$ ) between the BMPR1a-KO and WT forebrains. The observation that other receptors signaling through $S$ mad1/5/8 remain functional in the BMPR1a-null cells (Fig. 3) could explain why the KO mice have no change in total number of astrocytes. Finally, Nissl staining revealed no change in the cytoarchitecture of the $\mathrm{KO}$ cortex either at P0 (supplemental Fig. $1 A-F$, available at www.jneurosci.org as supplemental material) or at P20 (supplemental Fig. $1 G-L$, available at www.jneurosci.org as supplemental material), and there was no change in the overall density of cells in the forebrain or diencephalons (data not shown).

\section{GABAergic interneurons are specified from Olig1-expressing neural stem cells}

Several previous studies have shown that oligodendrocytes arise from progenitor cells that are also capable of differentiating into neurons (Williams et al., 1991; Levison and Goldman, 1997; Qian et al., 2000; Jakovcevski and Zecevic, 2005). Clonal analyses of basal telencephalon cells have further suggested that oligodendrocytes and GABAergic interneurons are derived from the same progenitor cells (He et al., 2001), and there is indirect evidence that Olig1-positive progenitors give rise to GABAergic interneurons (Yung et al., 2002). To specifically test the hypothesis that neural progenitor cells expressing Olig1 produce GABAergic interneurons in the dorsal cortex, we mated the Olig1cre/cre mice with floxed rosa26 mice. This generated a mouse (Olig1cre;R26) in which $\beta$ gal is expressed in Olig1-positive cell and its progeny. The dorsal forebrain cortex contained abundant $\beta$ gal-positive cells at P4 (Fig. 5A-D), indicating that cells originating from Olig1-positive progenitors had migrated throughout the cortex. To further confirm the specificity of expression of $\beta$ gal, we performed double immunohistochemistry for Olig1, cre recombinase (cre), and $\beta$ gal and found coexpression of these proteins in most cells at P4 (Fig. 5A-C,E). Next, to examine whether GABAergic interneurons are generated from Olig1-positive progenitors, we analyzed the localization of GABA and $\beta$ gal in coronal brain sections from P4 Olig1cre;R26 mice (Fig. 5F) and found that many cells in the dorsal cortex coexpressed these proteins, indicating that a proportion of cortical GABAergic interneurons originate from Olig1-positive cells. We also observed colabeling of cells in the P0 WT cortex with Olig1 and NeuN, which marks neuronal nuclei (Fig. $5 G-I$ ), supporting the hypothesis that olig1expressing progenitor cells give rise to cortical neurons. In all, these findings indicate that Olig1-positive neural precursor cells in the forebrain generate cortical GABAergic interneurons in vivo.

\section{Role of BMP signaling in generation of GABAergic interneurons}

In mice, GABAergic interneurons are generated after E12.5, enter the cortex on E13.5 (Lavdas et al., 1999; Stuhmer et al., 2002), and migrate into the cortical plate from E15.5 onward (Ang et al., 
2003; Nadarajah et al., 2003). Olig1 is expressed in progenitors as early as E10 and has been shown to be expressed in the ventricular zone of medial and lateral ganglionic eminences at E12.5 (Bansal et al., 2003). We examined the GABAergic interneurons in dorsomedial cortex (Fig. 6) because several BMP ligands are expressed in the dorsal telencephalic midline (Furuta et al., 1997; Mehler et al., 1997; Grove et al., 1998), and loss of BMPR1a receptor leads to patterning defects in the midline (Hebert et al., 2002). However, there was no significant difference in the number of GABA-positive cells between the $\mathrm{KO}$ and WT brains at P0 (data not shown).

\section{Role of BMP signaling in specification of interneuron subtypes}

To examine the effect of BMPR1a signaling on subsets of cortical GABAergic interneurons, we analyzed the expression of parvalbumin, calbindin, and calretinin calcium-binding proteins in the dorsomedial cortex. Together, these three subsets account for $\sim 80 \%$ of the cortical interneurons (DeFelipe, 1997). We found a distribution of these subpopulations of interneurons that is consistent with other studies (Hof et al., 1999; Tamamaki et al., 2003). There were numerous, large multipolar calbindin-expressing neurons in layers III/IV and V/VI (Fig. 7A-D). Other layers also contained some calbindin-positive neurons, but these had a lesser intensity of immunoreactivity, and the cell bodies were also smaller compared with the layers mentioned above. We found a significantly higher numbers of calbindinimmunoreactive neurons in the KO cortex at P0, but by P21, the WT and KO mice had no significant difference in calbindin interneuron numbers (Fig. 7E). We examined the calbindin-expressing neurons under higher magnification at birth and did not observe any morphological change in the $\mathrm{KO}$ mice. Because calbindin-positive neurons can be nonGABAergic (Gritti et al., 2003), we performed cell counts for neurons double labeled with calbindin and GABA, and our results show that at P21, the KO brains have a trend toward fewer numbers of GABAergic calbindin neurons, but the difference is of borderline significance ( $p=0.06 ; n=3$ ) (data not shown). Calbindin-expressing interneurons from the medial ganglionic eminence also migrate into the striatum (Eriksson et al., 2003), but we found no difference in their numbers in the striatum at birth (data not shown). Parvalbumin-immunoreactive interneurons were observed in layers III to $\mathrm{V}$ in both the KO and WT mice. These neurons had small, round cell bodies and a short thin process that extended from the soma (Fig. $8 E, F$ ). Calretinin was expressed very strongly in the superficial layer I or layer of CajalRetzius cells in both the KO and WT mice (Fig. 8A-D). Layers V and VI had faintly immunoreactive calretinin neurons compared with the layer I neurons. We did not observe any difference in the numbers of calretinin- or parvalbumin-immunoreactive interneurons between the KO and WT mice at either P0 or P21 (data
Wildtype

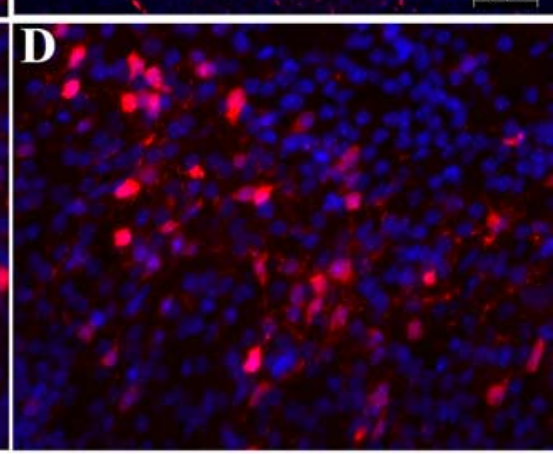

21
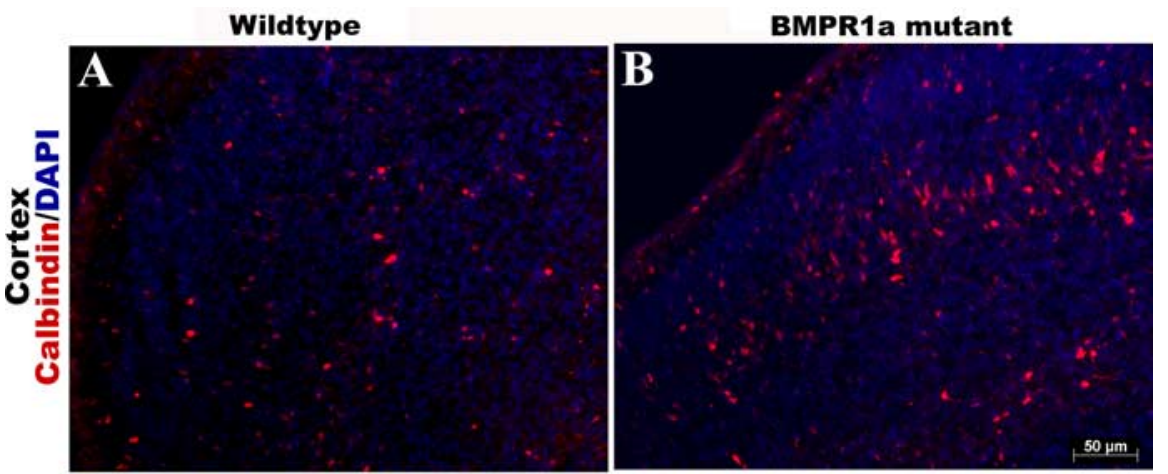

Ablation of BMPR1a leads to an increase in calbindin-expressing interneurons. $\boldsymbol{A}-\boldsymbol{E}$, Immunohistochemistry for interneurons in the cortex $(\boldsymbol{E})$ of $\mathrm{KO}$ mice compared with WT littermates, but the difference in their numbers is smaller at P21. $\boldsymbol{C}$, D, Higher-magnification view of layers V/VI. ${ }^{*} p=0.04, t$ test; $n=5$. Error bars represent SEM. DAPI, $4^{\prime}, 6^{\prime}-$ Diamidino-2phenylindole dihydrochloride.

not shown). These results indicate that BMPR1a signaling limits the development of calbindin but not parvalbumin or calretinin interneurons during normal development.

\section{BMPR1a mutation leads to an increase in rate of cell-cycle} reentry by SVZ progenitor cells

The increase in the number of oligodendrocytes and calbindin interneurons could result from enhanced numbers of progenitors, increased mitotic rates of the progenitor cells, decreased cell death of cells, or a combination of these factors. In parallel with the body weight, the KO brains were smaller in size than the WT at P20, but we did not observe any change in the cellular density. To examine the size of the progenitor pool, we analyzed the cortex of the forebrains for expression of PDGFR $\alpha$ and NG2 in coronal sections at P0 and P20 (supplemental Fig. 2, available at www.jneurosci.org as supplemental material). There were no significant differences in the percentage of cells expressing any of these markers in the cortex at either P0 or P20 (supplemental Fig. 2 , available at www.jneurosci.org as supplemental material). We also examined levels of NG2, PDGFR $\alpha$, CNPase, and PLP myelin proteins in whole-brain lysates at intermediate ages P10 and P13, but the results were the same as that seen at P20 (data not shown). Because oligodendrocyte progenitors first appear in the ventral 

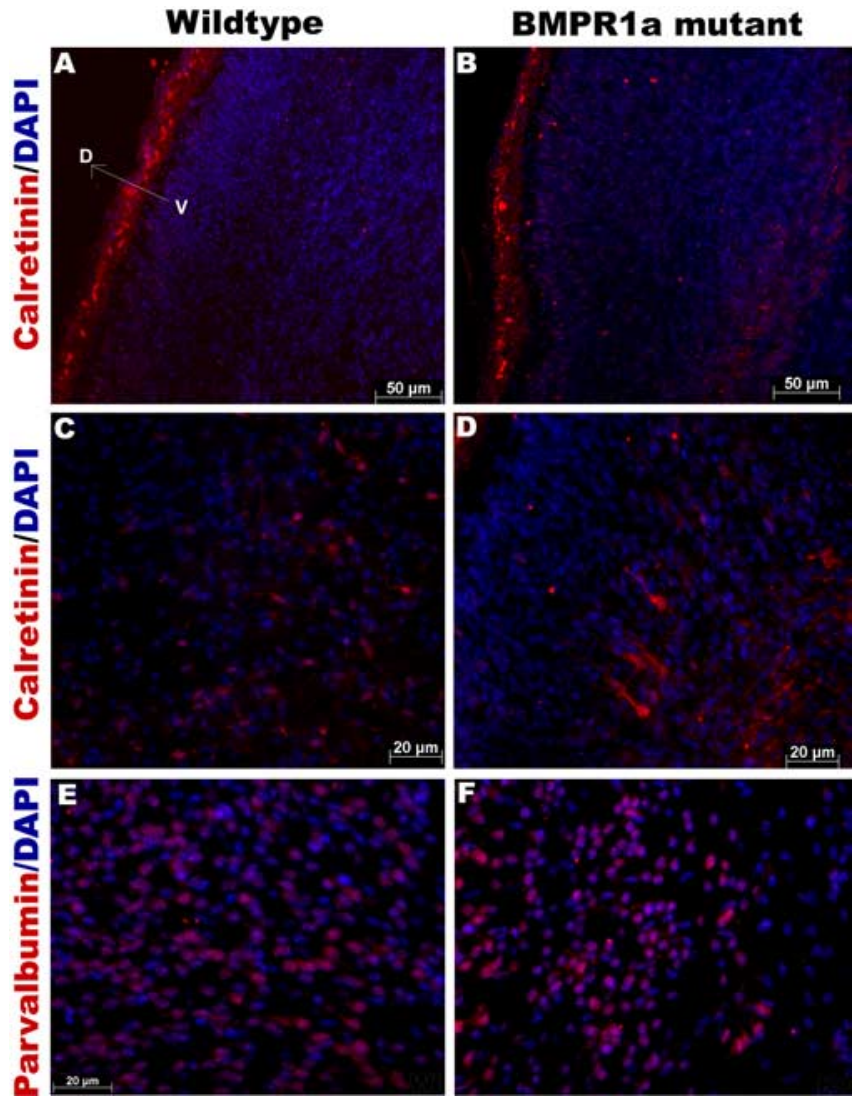

Figure 8. BMPR1a mutation has no effect on the number of calretinin- or parvalbuminexpressing interneurons. $\boldsymbol{A}-\boldsymbol{D}$, Immunohistochemistry for calretinin in coronal sections of $\mathrm{PO}$ mice shows no change in the number of calretinin-positive interneurons in the dorsomedial cortex of BMPR1a mutant mice compared with wild-type littermates. A higher magnification of layer $\mathrm{VI}$ is shown in $\boldsymbol{C}$ and $\boldsymbol{D}$, and layer I is shown in $\boldsymbol{A}$ and $\boldsymbol{B}$. $\boldsymbol{E}, \boldsymbol{F}$, Immunohistochemistry for parvalbumin of $\mathrm{PO}$ mice also shows no change in the number of parvalbumin-positive interneurons in the dorsomedial cortex of mutant mice compared with wild-type littermates $(n=5)$. DAPI, 4' ,6' -Diamidino-2-phenylindole dihydrochloride.

forebrain and then migrate dorsally and laterally into all parts of the forebrain (Tekki-Kessaris et al., 2001), we did separate counts for the dorsal and ventral forebrains and obtained similar results, indicating that the results of the cell counts were not attributable to delayed migration of oligodendroglial progenitors (data not shown).

To examine the rate of mitosis of neural stem/progenitor cells, we counted the percentage of progenitors in the lateral SVZ (Fig. 9) that were positive for PCNA, which labels cells undergoing DNA synthesis (Maga and Hubscher, 2003; Kisielewska et al., 2005). Adjacent sections were immunostained for Ki67, which is present in the active phases of cell cycle $\left(G_{1}, S, G_{2}\right.$, and $\left.M\right)$ and is absent from resting cells $\left(\mathrm{G}_{0}\right)$ (Scholzen and Gerdes, 2000; Kee et al., 2002). There was a 25\% decrease in Ki67-expressing progenitor cells in the $\mathrm{KO}$ mice at $\mathrm{P} 0$, although $\mathrm{KO}$ and WT forebrains had similar percentages of PCNA-expressing cells (Fig. 9F). In mammalian cells, extracellular signals regulate the length of $G_{1}$ phase, thereby affecting proliferation, whereas the length of Sphase remains relatively constant (Massague, 2004; Zhang and Li, 2005). A shortening of cell-cycle length results in an increase in the relative fraction of cells in S-phase. The percentage of progenitor cells in S-phase, also called the labeling index, thus provides a measure of the cell-cycle length (Chenn and Walsh, 2002). The KO brains had a fraction of cells 29\% higher in S-phase compared with WT brains (Fig. 9F).
The first oligodendrocyte progenitors are derived from Nkx2.1-positive cells in the medial ganglionic eminence. However, postnatally the majority of oligodendrocytes are generated from GSH2-expressing cells of the lateral and caudal ganglionic eminences, which later form the postnatal SVZ (Kessaris et al., 2006). We counted the number of GSH2 cells undergoing cell cycle in the SVZ at P0 and did not find any difference in either the overall numbers of GSH2-expressing cells in the SVZ (Fig. $10 A-F$ ) or GSH2 mRNA levels in the brain (data not shown). However, the KO brains had 20\% higher numbers of GSH2positive cells colabeled with Ki67 (Fig. 10C,F, H). In all, the KO mice have fewer total proliferating cells in the SVZ, but a higher proportion of these cells were GSH2-expressing progenitors, which produce oligodendrocytes and GABAergic interneurons (Corbin et al., 2003). These findings suggest that neural precursor cells in the SVZ of KO brains divide significantly faster than in WT brains, thus potentially enabling them to generate more oligodendroglia by P20. Because oligodendrocytes in the cortex are specified from Emxl-expressing progenitors in late postnatal ages, we performed immunohistochemistry in the $\mathrm{KO}$ brains at P20 and did not find any change in the proliferation of this population (data not shown), suggesting that Emx1+ cells are not regulated by BMPR1a signaling. Thus, the effect of BMPR1a seems to be restricted to the Gsh2 + progenitor population.

Because a reduction in cell death could also contribute to the increase in oligodendrocytes after ablation of BMPR1a, we examined apoptosis in $\mathrm{P0} \mathrm{KO}$ and WT brains by immunostaining for cleaved caspase 3 (Cohen, 1997; Earnshaw et al., 1999). There were very few apoptotic cells in the dorsal forebrains of either mouse, although at birth, the $\mathrm{KO}$ mice had an increase in apoptotic cells in the striatum with borderline significance $(p=$ $0.057 ; n=5$ ) (Fig. 11). Similar results were observed with TUNEL, which showed no difference between the KO and WT brains (data not shown).

\section{Discussion}

To determine the specific role of the BMPR1a subunit in neural lineage commitment, we ablated BMPR1a in progenitor cells expressing Olig1 using a cre/loxP genetic approach. BMP signaling through other type-1 receptors persisted in the Olig1-expressing cells, as evidenced by the presence of nuclear phospho-SMAD1/ $5 / 8$, a downstream effector of BMP signaling. Null mutation of BMPR1a in these cells resulted in a marked increase in the numbers of immature and mature oligodendrocytes (Fig. 2) in the telencephalon and an increase in the proportion of calbindinexpressing interneurons. Furthermore, we found an increase in the proportion of cycling progenitor cells in the SVZ undergoing $S$-phase, indicating a reduction in cell-cycle length. We conclude that signaling via the BMPRla receptor is essential for determining numbers of both oligodendrocytes and calbindin-positive interneurons, at least in part by regulating cell-cycle length in their progenitors.

Oligodendroglial progenitor cells are generated sequentially from Nkx2.1-, Gsh2-, and Emx1-expressing cells (Kessaris et al., 2006). Nkx2.1 lineage cells are abundant in the cortex at birth, but by P10 their numbers become very small. Gsh2-expressing progenitors in the ganglionic eminence generate both oligodendrocytes and cortical interneurons that express calbindin and parvalbumin (Anderson et al., 2001; Wichterle et al., 2001; Corbin et al., 2003; Xu et al., 2004), and by P20, the majority of oligodendrocytes are derived from the Gsh2-expressing progenitors (Kessaris et al., 2006). Gsh2 controls the size of the SVZ precursor pool, and mutating Gsh2 results in a decrease in progenitor cell 
numbers in the SVZ (Szucsik et al., 1997; Toresson and Campbell, 2001). We found that null mutation of BMPR1a in olig1expressing cells did not alter specification of the Gsh2 cells but that it shortened the cell-cycle length in them (Fig. 10). Oligodendrocyte precursors are a heterogeneous population that divide $0-8$ times before differentiating (Temple and Raff, 1986). However, the progenitors stop dividing and differentiate at the same time, indicating that the intrinsic clock in oligodendrocyte precursors counts time and not the number of cell divisions (Gao et al., 1997; Raff et al., 1998). Thus, shortening of the cell cycle in these cells would be expected to lead to an extra round of cell division, which would in turn lead to an increased number of mature oligodendrocytes, as was observed in the BMPR1a mutant mice at P20. This might also slightly delay the generation of mature progeny to replace the diminishing $\mathrm{Nkx} 2.1$-derived pool of cells, explaining the decrease in CNPase-expressing oligodendrocytes at P0 (Fig. 2).

Programmed cell death occurs postnatally in proliferating cells of the SVZ (Thomaidou et al., 1997) and could also potentially modulate the production of certain lineage species while sparing others. We found a trend toward an increase in the numbers of apoptotic cells in the ventral diencephalon of BMPR1a-KO, but it was of only borderline significance (Fig. 11). Nevertheless, this does not rule out the possibility that low ongoing levels of cell death in embryonic ages could also contribute to the lack of an increase in oligodendroglial progenitors at $\mathrm{PO}$ in the $\mathrm{KO}$ mice.

BMP signaling inhibits generation of oligodendroglia by neural progenitor cells in vitro and in vivo (Gross et al., 1996; Mabie et al., 1997; Grinspan et al., 2000; Mekki-Dauriac et al., 2002; Samanta and Kessler, 2004), and we found that ablation of BMPR1a increased oligodendroglial cell number. We therefore conclude that BMPR1a mediates suppressive effects of BMPs on oligodendroglial progenitors. However, a previous study has reported that overexpression of dominant-negative (dn) BMPR1b, but not dnBMPR1a, in cultured adult hippocampal progenitors increases immature oligodendroglial numbers (Brederlau et al., 2004). This is in contrast to our findings, possibly reflecting differences between our in vivo data and the in vitro data in that study, differences between developing animals and the adult cells used in that study, or examination in that study of a restricted subset of hippocampal progenitor cells that do not normally generate the major populations of oligodendrocytes in the brain. Because we ablated BMPR1a in vivo specifically in the population of progenitor cells that normally generates oligodendrocytes in the adult brain, our findings strongly support the hypothesis that intact BMPR1a signaling is essential for regulating oligodendroglial differentiation in the telencephalon in vivo.
Wildtype
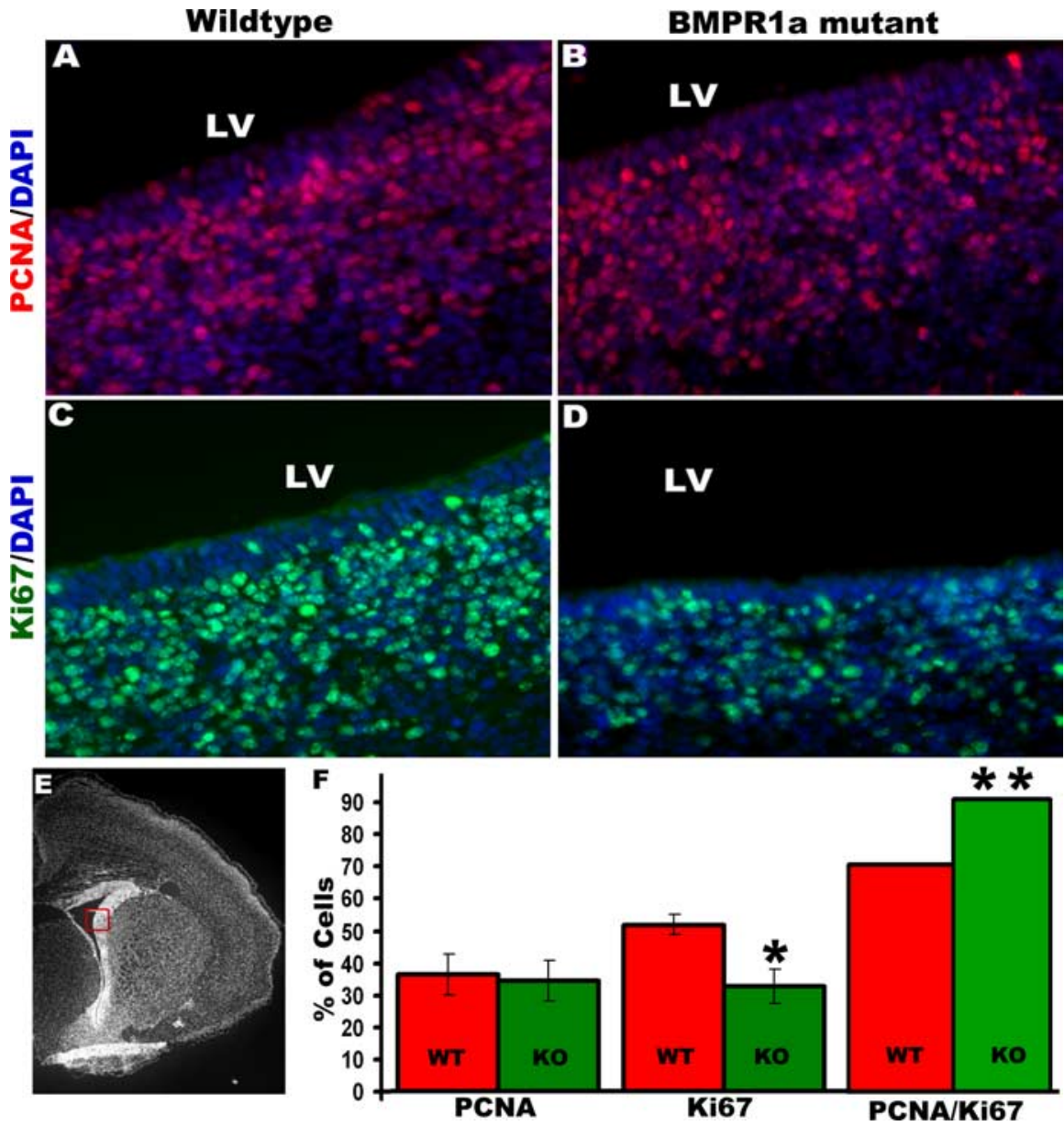

Ki67
Figure 9. Subventricular zone cells in the BMPR1a-null mutant mice have a shortened cell-cycle length. $\boldsymbol{A}-\boldsymbol{D}, \boldsymbol{F}$, Immunohistochemistry was done for PCNA $(\boldsymbol{A}, \boldsymbol{B}, \boldsymbol{F})$ and $\mathrm{Ki} 67(\boldsymbol{C}, \boldsymbol{D}, \boldsymbol{F})$ in coronal brain sections from P0 mice, and cell counts were done using 作 tion in cell-cycle length. ${ }^{*} p=0.02, t$ test, $n=5 ;{ }^{* *} p=0.003, n=5$. Error bars represent SEM. DAPI, $4^{\prime}, 6^{\prime}$-Diamidino-2phenylindole dihydrochloride; LV, lateral ventricle.

Previous studies found that blocking endogenous BMP signaling by expressing dnBMPR1b receptor increased the generation of interneurons in the dorsomedial wall in culture, suggesting that BMPs normally inhibit interneuron specification (Gulacsi and Lillien, 2003). In contrast, studies by another group found that BMP treatment of cultured striatal cells increased the number of calbindinpositive interneurons, although this effect appeared to be an indirect one mediated by astrocytes and other growth factors (Gratacos et al., 2001, 2002). In our study, null mutation of BMPR1a did not alter the total number of interneurons in the telencephalon, although there was a trend toward an increase. Instead, we found an increase in the number of calbindin-expressing interneurons without any change in total GABAergic interneurons or overall neuron numbers. Because calbindin, parvalbumin, and calretinin together constitute $80 \%$ of cortical interneurons, there could be a complimentary decrease in an unexamined neuronal population, accounting for the lack of change in overall neuron numbers. Calbindin interneurons are known to undergo a phenotypic shift in the second and third postnatal weeks, resulting in a decrease in their numbers by P21 (Alcantara et al., 1993, 1996). Nevertheless, our findings suggest that the primary effect of BMPR la signaling on interneuron specification in vivo is specifically to inhibit calbindin interneurons. 

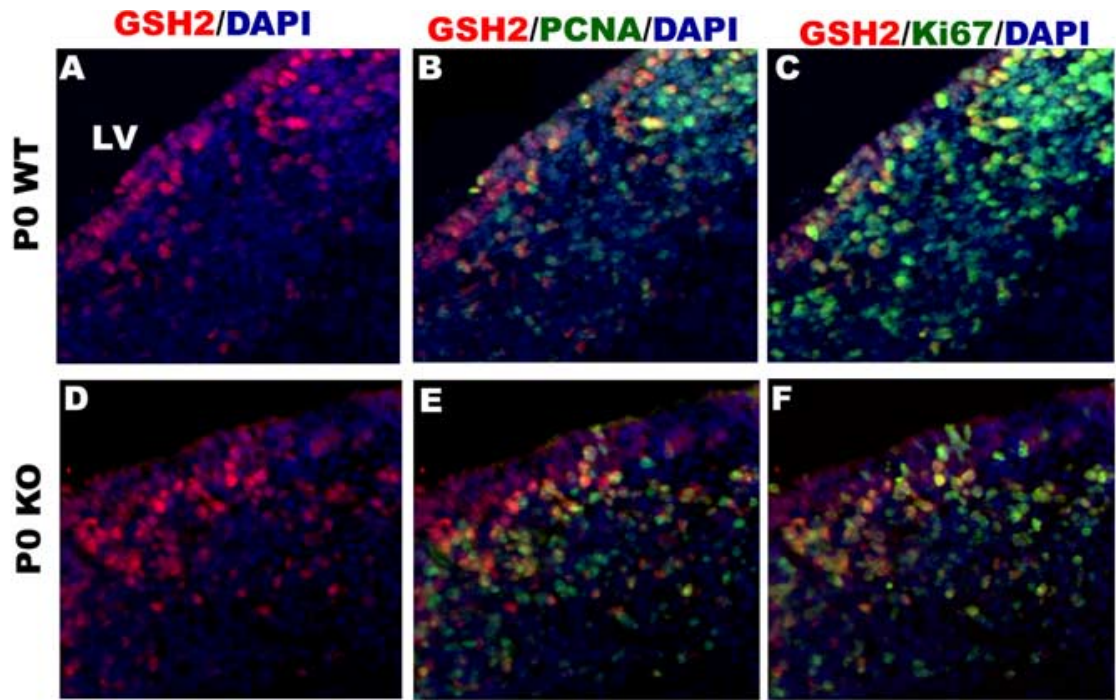

G
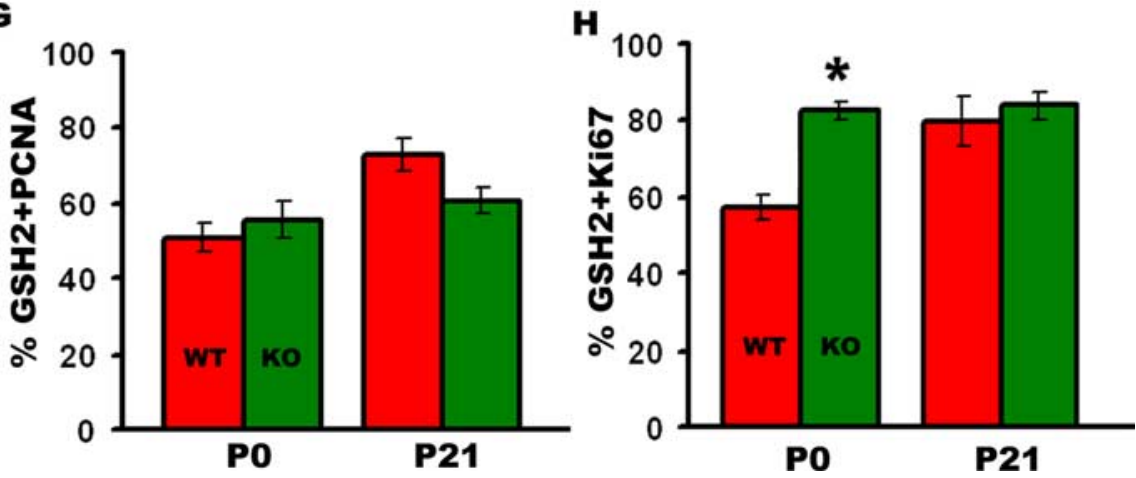

Figure 10. BMPR1a-null mutant mice have more GSH2-positive cells undergoing cell cycle in the subventricular zone. Immunohistochemistry was done at P0 and P21 for GSH2-positive cells in the subventricular zone double labeled with PCNA and Ki67. $\boldsymbol{A}, \boldsymbol{D}$, There was no difference in total numbers of GSH2-expressing cells between WT and $K 0 . \boldsymbol{B}, \boldsymbol{C}, \boldsymbol{E}-\boldsymbol{H}$, The percentage of GSH2-positive cells double labeled with PCNA is not changed in the $K 0$ mice at PO or P21 $(\boldsymbol{B}, \boldsymbol{E}, \boldsymbol{G})$; however, the $K 0$ mice have a greater percentage of GSH2-expressing cells labeled with Ki67 at P0 $(\boldsymbol{C}, \boldsymbol{F}, \boldsymbol{H}) .{ }^{*} p=0.019, t$ test, $n=3$. DAPI, $4^{\prime}, 6^{\prime}$-Diamidino2-phenylindole dihydrochloride; LV, lateral ventricle.

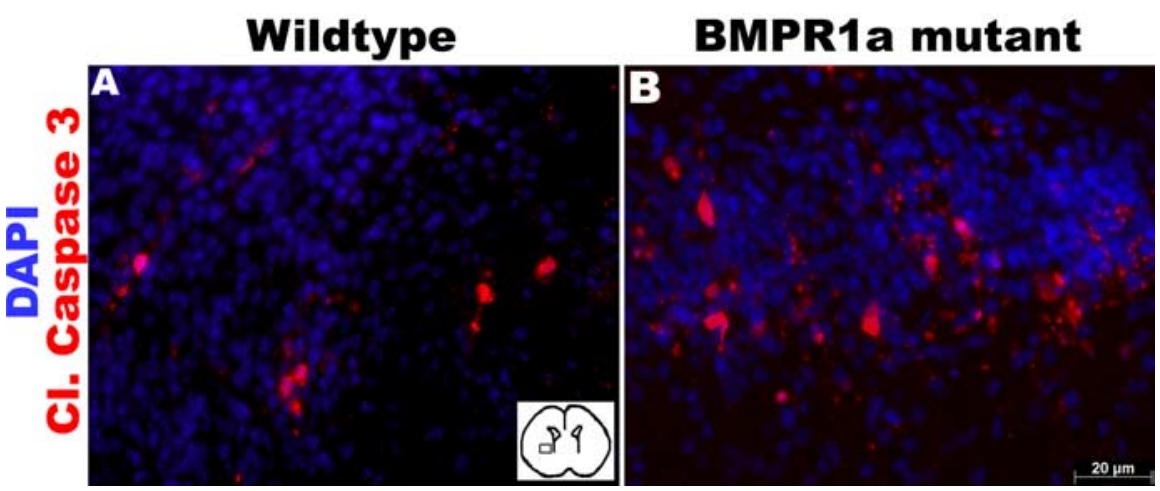

Figure 11. BMPR1a mutation does not alter apoptosis in the ventral forebrain. $\boldsymbol{A}, \boldsymbol{B}$, Immunohistochemistry was done for cleaved caspase 3 (Cl. Caspase 3 ) in the ventral forebrain of PO BMPR1a mutant and wild-type mice. Inset, Area of ventral forebrain in which cell count was done. DAPI, 4',6' -Diamidino-2-phenylindole dihydrochloride.

BMP4 signaling increases the production of astrocytes from progenitor cells in vitro and in vivo (Gross et al., 1996; Samanta and Kessler, 2004). Furthermore, double-null mutations of both Olig1 and Olig2 in mice result in inhibition of oligodendrogenesis coupled with enhanced generation of astrocytes (Zhou and Anderson, 2002). In our studies, we did not observe any change in total numbers of GFAP-expressing astrocytes in the KO brains (Fig. 4). Because
Olig1-expressing progenitors give rise to astrocytes (supplemental Fig. 3, available at www.jneurosci.org as supplemental material), this could be explained by the fact that BMP signaling via other BMP receptors like BMPR1b/Alk6 and ActR1a/Alk2 is intact in the Olig1-positive progenitors and that astrocyte numbers may be regulated by BMPR1b or Alk2. BMP4 promotes the maturation of GFAP-expressing astrocytes (Bonaguidi et al., 2005) by signaling via the noncanonical p38-mitogen-activated protein kinase (p38-MAPK) pathway without regulating their total numbers (C. Czeisler and J. A. Kessler, unpublished observation). Because BMPR1a is known to signal through the p38-MAPK pathway (Shibuya et al., 1998), it is possible that there are changes in cellular morphology in the $\mathrm{KO}$ animals despite the lack of change in astrocyte numbers.

It is unclear why the BMPR1a animals fail to thrive and die as young adults. The increase in mature oligodendrocytes and calbindin-expressing interneurons is unlikely to cause death of the mice. Oligexpressing progenitor cells are important for generation of motor neurons, but the KO mice did not exhibit any difficulty in walking, did not exhibit any difference in suckling behavior, and gained weight normally in the first 2 weeks. Furthermore, there were no detectable abnormalities in motor neurons. Because the mice appeared normal at birth but failed to gain weight after 2 weeks of age, the failure to thrive may reflect the loss of some ongoing postnatal role for BMPR1a signaling. We have not been able to detect expression of the transgene outside of the nervous system, but it is still also possible that the failure to thrive reflects disruption of an extraneural function for BMPR1a signaling.

\section{References}

Ahn K, Mishina Y, Hanks MC, Behringer RR, Crenshaw III EB (2001) BMPR-IA signaling is required for the formation of the apical ectodermal ridge and dorsal-ventral patterning of the limb. Development 128:4449-4461.

Alcantara S, Ferrer I, Soriano E (1993) Postnatal development of parvalbumin and calbindin D28K immunoreactivities in the cerebral cortex of the rat. Anat Embryol (Berl) 188:63-73.

Alcantara S, de Lecea L, Del Rio JA, Ferrer I, Soriano E (1996) Transient colocalization of parvalbumin and calbindin D28k in the postnatal cerebral cortex: evidence for a phenotypic shift in developing nonpyramidal neurons. Eur J Neurosci 8:1329-1339.

Anderson SA, Qiu M, Bulfone A, Eisenstat DD, Meneses J, Pedersen R, Rubenstein JL (1997) Mutations of the homeobox genes Dlx-1 and Dlx-2 disrupt the striatal subventricular zone and differentiation of late born striatal neurons. Neuron 19:27-37.

Anderson SA, Marin O, Horn C, Jennings K, Rubenstein JL (2001) Distinct 
cortical migrations from the medial and lateral ganglionic eminences. Development 128:353-363.

Andl T, Ahn K, Kairo A, Chu EY, Wine-Lee L, Reddy ST, Croft NJ, CebraThomas JA, Metzger D, Chambon P, Lyons KM, Mishina Y, Seykora JT, Crenshaw III EB, Millar SE (2004) Epithelial Bmprla regulates differentiation and proliferation in postnatal hair follicles and is essential for tooth development. Development 131:2257-2268.

Ang Jr ES, Haydar TF, Gluncic V, Rakic P (2003) Four-dimensional migratory coordinates of GABAergic interneurons in the developing mouse cortex. J Neurosci 23:5805-5815.

Bansal R, Lakhina V, Remedios R, Tole S (2003) Expression of FGF receptors 1,2, 3 in the embryonic and postnatal mouse brain compared with Pdgfralpha, Olig2 and Plp/dm20: implications for oligodendrocyte development. Dev Neurosci 25:83-95.

Bonaguidi MA, McGuire T, Hu M, Kan L, Samanta J, Kessler JA (2005) LIF and BMP signaling generate separate and discrete types of GFAPexpressing cells. Development 132:5503-5514.

Brederlau A, Faigle R, Elmi M, Zarebski A, Sjoberg S, Fujii M, Miyazono K, Funa K (2004) The bone morphogenetic protein type Ib receptor is a major mediator of glial differentiation and cell survival in adult hippocampal progenitor cell culture. Mol Biol Cell 15:3863-3875.

Chenn A, Walsh CA (2002) Regulation of cerebral cortical size by control of cell cycle exit in neural precursors. Science 297:365-369.

Cohen GM (1997) Caspases: the executioners of apoptosis. Biochem J 326:1-16.

Corbin JG, Rutlin M, Gaiano N, Fishell G (2003) Combinatorial function of the homeodomain proteins $\mathrm{Nkx} 2.1$ and Gsh2 in ventral telencephalic patterning. Development 130:4895-4906.

Davis S, Miura S, Hill C, Mishina Y, Klingensmith J (2004) BMP receptor IA is required in the mammalian embryo for endodermal morphogenesis and ectodermal patterning. Dev Biol 270:47-63.

DeFelipe J (1997) Types of neurons, synaptic connections and chemical characteristics of cells immunoreactive for calbindin-D28K, parvalbumin and calretinin in the neocortex. J Chem Neuroanat 14:1-19.

Dewulf N, Verschueren K, Lonnoy O, Moren A, Grimsby S, Vande Spiegle K, Miyazono K, Huylebroeck D, Ten Dijke P (1995) Distinct spatial and temporal expression patterns of two type I receptors for bone morphogenetic proteins during mouse embryogenesis. Endocrinology 136:2652-2663.

Earnshaw WC, Martins LM, Kaufmann SH (1999) Mammalian caspases: structure, activation, substrates, and functions during apoptosis. Annu Rev Biochem 68:383-424.

Eriksson C, Bjorklund A, Wictorin K (2003) Neuronal differentiation following transplantation of expanded mouse neurosphere cultures derived from different embryonic forebrain regions. Exp Neurol 184:615-635.

Furuta Y, Piston DW, Hogan BL (1997) Bone morphogenetic proteins (BMPs) as regulators of dorsal forebrain development. Development 124:2203-2212.

Gao FB, Durand B, Raff M (1997) Oligodendrocyte precursor cells count time but not cell divisions before differentiation. Curr Biol 7:152-155.

Gaussin V, Morley GE, Cox L, Zwijsen A, Vance KM, Emile L, Tian Y, Liu J, Hong C, Myers D, Conway SJ, Depre C, Mishina Y, Behringer RR, Hanks MC, Schneider MD, Huylebroeck D, Fishman GI, Burch JB, Vatner SF (2005) Alk3/Bmprla receptor is required for development of the atrioventricular canal into valves and annulus fibrosus. Circ Res 97:219-226.

Gratacos E, Checa N, Perez-Navarro E, Alberch J (2001) Brain-derived neurotrophic factor (BDNF) mediates bone morphogenetic protein-2 (BMP-2) effects on cultured striatal neurones. J Neurochem 79:747-755.

Gratacos E, Gavalda N, Alberch J (2002) Bone morphogenetic protein-6 is a neurotrophic factor for calbindin-positive striatal neurons. J Neurosci Res 70:638-644.

Grinspan JB, Edell E, Carpio DF, Beesley JS, Lavy L, Pleasure D, Golden JA (2000) Stage-specific effects of bone morphogenetic proteins on the oligodendrocyte lineage. J Neurobiol 43:1-17.

Gritti I, Manns ID, Mainville L, Jones BE (2003) Parvalbumin, calbindin, or calretinin in cortically projecting and GABAergic, cholinergic, or glutamatergic basal forebrain neurons of the rat. J Comp Neurol 458:11-31.

Gross RE, Mehler MF, Mabie PC, Zang Z, Santschi L, Kessler JA (1996) Bone morphogenetic proteins promote astroglial lineage commitment by mammalian subventricular zone progenitor cells. Neuron 17:595-606.

Grove EA, Tole S, Limon J, Yip L, Ragsdale CW (1998) The hem of the embryonic cerebral cortex is defined by the expression of multiple Wnt genes and is compromised in Gli3-deficient mice. Development 125:2315-2325.

Gulacsi A, Lillien L (2003) Sonic hedgehog and bone morphogenetic protein regulate interneuron development from dorsal telencephalic progenitors in vitro. J Neurosci 23:9862-9872.

He W, Ingraham C, Rising L, Goderie S, Temple S (2001) Multipotent stem cells from the mouse basal forebrain contribute GABAergic neurons and oligodendrocytes to the cerebral cortex during embryogenesis. J Neurosci 21:8854-8862.

Hebert JM, Mishina Y, McConnell SK (2002) BMP signaling is required locally to pattern the dorsal telencephalic midline. Neuron 35:1029-1041.

Hof PR, Glezer II, Conde F, Flagg RA, Rubin MB, Nimchinsky EA, Vogt Weisenhorn DM (1999) Cellular distribution of the calcium-binding proteins parvalbumin, calbindin, and calretinin in the neocortex of mammals: phylogenetic and developmental patterns. J Chem Neuroanat 16:77-116.

Jakovcevski I, Zecevic N (2005) Olig transcription factors are expressed in oligodendrocyte and neuronal cells in human fetal CNS. J Neurosci 25:10064-10073.

Kee N, Sivalingam S, Boonstra R, Wojtowicz JM (2002) The utility of Ki-67 and BrdU as proliferative markers of adult neurogenesis. J Neurosci Methods 115:97-105.

Kessaris N, Fogarty M, Iannarelli P, Grist M, Wegner M, Richardson WD (2006) Competing waves of oligodendrocytes in the forebrain and postnatal elimination of an embryonic lineage. Nat Neurosci 9:173-179.

Kisielewska J, Lu P, Whitaker M (2005) GFP-PCNA as an S-phase marker in embryos during the first and subsequent cell cycles. Biol Cell 97:221-229.

Koenig BB, Cook JS, Wolsing DH, Ting J, Tiesman JP, Correa PE, Olson CA, Pecquet AL, Ventura F, Grant RA, et al (1994) Characterization and cloning of a receptor for BMP-2 and BMP-4 from NIH 3T3 cells. Mol Cell Biol 14:5961-5974.

Lavdas AA, Grigoriou M, Pachnis V, Parnavelas JG (1999) The medial ganglionic eminence gives rise to a population of early neurons in the developing cerebral cortex. J Neurosci 19:7881-7888.

Levison SW, Goldman JE (1997) Multipotential and lineage restricted precursors coexist in the mammalian perinatal subventricular zone. J Neurosci Res 48:83-94.

Li W, Cogswell CA, LoTurco JJ (1998) Neuronal differentiation of precursors in the neocortical ventricular zone is triggered by BMP. J Neurosci 18:8853-8862.

Lu QR, Yuk D, Alberta JA, Zhu Z, Pawlitzky I, Chan J, McMahon AP, Stiles CD, Rowitch DH (2000) Sonic hedgehog-regulated oligodendrocyte lineage genes encoding bHLH proteins in the mammalian central nervous system. Neuron 25:317-329.

Lu QR, Sun T, Zhu Z, Ma N, Garcia M, Stiles CD, Rowitch DH (2002) Common developmental requirement for Olig function indicates a motor neuron/oligodendrocyte connection. Cell 109:75-86.

Mabie PC, Mehler MF, Marmur R, Papavasiliou A, Song Q, Kessler JA (1997) Bone morphogenetic proteins induce astroglial differentiation of oligodendroglial-astroglial progenitor cells. J Neurosci 17:4112-4120.

Mabie PC, Mehler MF, Kessler JA (1999) Multiple roles of bone morphogenetic protein signaling in the regulation of cortical cell number and phenotype. J Neurosci 19:7077-7088.

Maga G, Hubscher U (2003) Proliferating cell nuclear antigen (PCNA): a dancer with many partners. J Cell Sci 116:3051-3060.

Massague J (2004) G1 cell-cycle control and cancer. Nature 432:298-306.

Mehler MF, Marmur R, Gross R, Mabie PC, Zang Z, Papavasiliou A, Kessler JA (1995) Cytokines regulate the cellular phenotype of developing neural lineage species. Int J Dev Neurosci 13:213-240.

Mehler MF, Mabie PC, Zhang D, Kessler JA (1997) Bone morphogenetic proteins in the nervous system. Trends Neurosci 20:309-317.

Mekki-Dauriac S, Agius E, Kan P, Cochard P (2002) Bone morphogenetic proteins negatively control oligodendrocyte precursor specification in the chick spinal cord. Development 129:5117-5130.

Ming Kwan K, Li AG, Wang XJ, Wurst W, Behringer RR (2004) Essential roles of BMPR-IA signaling in differentiation and growth of hair follicles and in skin tumorigenesis. Genesis 39:10-25.

Mishina Y, Suzuki A, Ueno N, Behringer RR (1995) Bmpr encodes a type I bone morphogenetic protein receptor that is essential for gastrulation during mouse embryogenesis. Genes Dev 9:3027-3037.

Mishina Y, Hanks MC, Miura S, Tallquist MD, Behringer RR (2002) Generation of Bmpr/Alk3 conditional knockout mice. Genesis 32:69-72. 
Mishina Y, Starbuck MW, Gentile MA, Fukuda T, Kasparcova V, Seedor JG, Hanks MC, Amling M, Pinero GJ, Harada S, Behringer RR (2004) Bone morphogenetic protein type IA receptor signaling regulates postnatal osteoblast function and bone remodeling. J Biol Chem 279:27560-27566.

Nadarajah B, Alifragis P, Wong RO, Parnavelas JG (2003) Neuronal migration in the developing cerebral cortex: observations based on real-time imaging. Cereb Cortex 13:607-611.

Nishiyama A, Lin XH, Giese N, Heldin CH, Stallcup WB (1996) Colocalization of NG2 proteoglycan and PDGF alpha-receptor on O2A progenitor cells in the developing rat brain. J Neurosci Res 43:299-314.

Panchision DM, Pickel JM, Studer L, Lee SH, Turner PA, Hazel TG, McKay RD (2001) Sequential actions of BMP receptors control neural precursor cell production and fate. Genes Dev 15:2094-2110.

Poncet C, Soula C, Trousse F, Kan P, Hirsinger E, Pourquie O, Duprat AM, Cochard P (1996) Induction of oligodendrocyte progenitors in the trunk neural tube by ventralizing signals: effects of notochord and floor plate grafts, and of sonic hedgehog. Mech Dev 60:13-32.

Pringle NP, Yu WP, Guthrie S, Roelink H, Lumsden A, Peterson AC, Richardson WD (1996) Determination of neuroepithelial cell fate: induction of the oligodendrocyte lineage by ventral midline cells and sonic hedgehog. Dev Biol 177:30-42.

Qian X, Shen Q, Goderie SK, He W, Capela A, Davis AA, Temple S (2000) Timing of CNS cell generation: a programmed sequence of neuron and glial cell production from isolated murine cortical stem cells. Neuron 28:69-80.

Raff MC, Durand B, Gao FB (1998) Cell number control and timing in animal development: the oligodendrocyte cell lineage. Int J Dev Biol 42:263-267.

Samanta J, Kessler JA (2004) Interactions between ID and OLIG proteins mediate the inhibitory effects of BMP4 on oligodendroglial differentiation. Development 131:4131-4142.

Scholzen T, Gerdes J (2000) The Ki-67 protein: from the known and the unknown. J Cell Physiol 182:311-322.

See J, Zhang X, Eraydin N, Mun SB, Mamontov P, Golden JA, Grinspan JB (2004) Oligodendrocyte maturation is inhibited by bone morphogenetic protein. Mol Cell Neurosci 26:481-492.

See J, Mamontov P, Ahn K, Wine-Lee L, Crenshaw III EB, Grinspan JB (2007) BMP signaling mutant mice exhibit glial cell maturation defects. Mol Cell Neurosci 35:171-182.

Shibuya H, Iwata H, Masuyama N, Gotoh Y, Yamaguchi K, Irie K, Matsumoto K, Nishida E, Ueno N (1998) Role of TAK1 and TAB1 in BMP signaling in early Xenopus development. EMBO J 17:1019-1028.

Stottmann RW, Choi M, Mishina Y, Meyers EN, Klingensmith J (2004) $\mathrm{BMP}$ receptor IA is required in mammalian neural crest cells for development of the cardiac outflow tract and ventricular myocardium. Development 131:2205-2218.

Stuhmer T, Puelles L, Ekker M, Rubenstein JL (2002) Expression from a Dlx gene enhancer marks adult mouse cortical GABAergic neurons. Cereb Cortex 12:75-85.

Szucsik JC, Witte DP, Li H, Pixley SK, Small KM, Potter SS (1997) Altered forebrain and hindbrain development in mice mutant for the Gsh-2 homeobox gene. Dev Biol 191:230-242.

Tamamaki N, Yanagawa Y, Tomioka R, Miyazaki J, Obata K, Kaneko T (2003) Green fluorescent protein expression and colocalization with cal- retinin, parvalbumin, and somatostatin in the GAD67-GFP knock-in mouse. J Comp Neurol 467:60-79.

Tekki-Kessaris N, Woodruff R, Hall AC, Gaffield W, Kimura S, Stiles CD, Rowitch DH, Richardson WD (2001) Hedgehog-dependent oligodendrocyte lineage specification in the telencephalon. Development 128:2545-2554

Temple S, Raff MC (1986) Clonal analysis of oligodendrocyte development in culture: evidence for a developmental clock that counts cell divisions. Cell 44:773-779.

ten Dijke P, Korchynskyi O, Valdimarsdottir G, Goumans MJ (2003) Controlling cell fate by bone morphogenetic protein receptors. Mol Cell Endocrinol 211:105-113.

Thomaidou D, Mione MC, Cavanagh JF, Parnavelas JG (1997) Apoptosis and its relation to the cell cycle in the developing cerebral cortex. J Neurosci 17:1075-1085.

Toresson H, Campbell K (2001) A role for Gsh1 in the developing striatum and olfactory bulb of Gsh2 mutant mice. Development 128:4769-4780.

Wichterle H, Turnbull DH, Nery S, Fishell G, Alvarez-Buylla A (2001) In utero fate mapping reveals distinct migratory pathways and fates of neurons born in the mammalian basal forebrain. Development 128:3759-3771.

Williams BP, Read J, Price J (1991) The generation of neurons and oligodendrocytes from a common precursor cell. Neuron 7:685-693.

Wine-Lee L, Ahn KJ, Richardson RD, Mishina Y, Lyons KM, Crenshaw III EB (2004) Signaling through BMP type 1 receptors is required for development of interneuron cell types in the dorsal spinal cord. Development 131:5393-5403.

Xu Q, Cobos I, De La Cruz E, Rubenstein JL, Anderson SA (2004) Origins of cortical interneuron subtypes. J Neurosci 24:2612-2622.

Xu Q, Wonders CP, Anderson SA (2005) Sonic hedgehog maintains the identity of cortical interneuron progenitors in the ventral telencephalon. Development 132:4987-4998.

Yi SE, Daluiski A, Pederson R, Rosen V, Lyons KM (2000) The type I BMP receptor BMPRIB is required for chondrogenesis in the mouse limb. Development 127:621-630.

Yuhki M, Yamada M, Kawano M, Iwasato T, Itohara S, Yoshida H, Ogawa M, Mishina Y (2004) BMPR1A signaling is necessary for hair follicle cycling and hair shaft differentiation in mice. Development 131:1825-1833.

Yung SY, Gokhan S, Jurcsak J, Molero AE, Abrajano JJ, Mehler MF (2002) Differential modulation of BMP signaling promotes the elaboration of cerebral cortical GABAergic neurons or oligodendrocytes from a common sonic hedgehog-responsive ventral forebrain progenitor species. Proc Natl Acad Sci USA 99:16273-16278.

Zhang D, Mehler MF, Song Q, Kessler JA (1998) Development of bone morphogenetic protein receptors in the nervous system and possible roles in regulating trkC expression. J Neurosci 18:3314-3326.

Zhang J, Li L (2005) BMP signaling and stem cell regulation. Dev Biol 284:1-11.

Zhou Q, Anderson DJ (2002) The bHLH transcription factors OLIG2 and OLIG1 couple neuronal and glial subtype specification. Cell 109:61-73.

Zhou Q, Wang S, Anderson DJ (2000) Identification of a novel family of oligodendrocyte lineage-specific basic helix-loop-helix transcription factors. Neuron 25:331-343.

Zhu G, Mehler MF, Mabie PC, Kessler JA (1999) Developmental changes in progenitor cell responsiveness to cytokines. J Neurosci Res 56:131-145. 